\title{
Characteristics and Technological Aspects of the Egyptian Cheeses
}

\author{
Ahmed R. A. Hammam ${ }^{1,2 *}$, Mohamed S. Elfaruk ${ }^{1}$, \\ Mahmoud E. Ahmed ${ }^{2}$ and Venkateswarlu Sunkesula ${ }^{1}$ \\ ${ }^{1}$ Dairy and Food Science Department, South Dakota State University, \\ Brookings 57007, SD, USA \\ ${ }^{2}$ Dairy Science Department, Faculty of Agriculture, Assiut University, Assiut, Egypt \\ *Corresponding author
}

K e y w o r d s
Cheese
composition,
Domiati cheese,
Karish cheese, Mish
cheese, Ras cheese

A B S T R A C T
Cheese is a dairy product produced by precipitating the casein of milk using starter cultures and rennet (e. $g$. enzymes) through a chemical process. Cheese is different among countries and could be made from cow's, buffalo's, goat's, sheep's, or camel's milk. Cheese is a good source of protein and minerals (such as calcium and phosphorus) that have nutritional values. Cheese is also essential for building healthy bones and teeth and provide the brain with essential fatty acids. Different technologies and different milk have been utilized to manufacture the traditional Egyptian cheeses, which resulted in differences in the composition, cheese types, and flavors. Consequently, this work aims to review and highlight the technological and chemical aspects of the most popular Egyptian cheese varieties, namely, Domiati cheese, Karish cheese, Mish cheese, and Ras cheese made from different sources of milk during ripening; and to briefly discuss the health benefits of the cheese.

\section{Introduction}

Cheese is a preserved form of milk that can be obtained by using starter cultures and enzymes to coagulate the milk through a chemical process in several steps, as shown in Figure 1 (Fox and McSweeney, 2004; Hammam et al., 2018; Wolfschoon, 2010). Cheese is well known for its nutritional value and longevity; however, it has different tastes, textures, and styles depending on many parameters, such as the starter cultures, the type of milk, the ripening or aging, and the manufacturing conditions.

Cheese can be made from cow's, buffalo's, camel's, goat's, and sheep's milk. Cheese is divided into three main categories, including 
soft cheese, semi-hard cheese, and hard cheese. The soft cheese is un-ripened, made locally from sour milk, and consumed on the same day of processing. The medium or semihard cheese is not consumed widely compared to the soft and hard cheese. The hard cheese is ripened by rennet enzymes (Hellmuth and van den Brink, 2013) or bacteria.

There are many varieties of cheese in Egypt, such as Domiati cheese and Karish cheese (soft cheeses), Mish cheese (pickled cheese), and Ras or Roumy cheese (hard cheese), which are widely consumed and produced in Egypt, Arab counties, and Mediterranean countries. Cheese is a rich source of calcium and protein. It also contains large quantities of vitamins $A, B_{12}$, zinc, and phosphorus. Cheese is essential to the body because of its critical role in building the bones and teeth and providing the brain with essential fatty acids.

This review aims to present the technological and chemical properties of the most common traditional cheeses in Egypt; additionally, some of the health benefits of these cheeses to the human body.

\section{Domiati cheese}

Domiati cheese is a soft cheese and consumed widely in Egypt, Arab counties, Mediterranean countries, and Europe. Domiati cheese name was related to the governorate of Damietta (Abou-Donia, 1996) which is similar to Greece Feta cheese. Domiati cheese originated in Egypt in 332 BC (Abou-Donia, 1996). Domiati cheese was studied by many researchers in Egypt (Ayad, 2009; El-Baradei et al., 2007a; A. H. Fahmi and Sharara, 1950) and other countries, e.g., Denmark, Germany, India, Iraq, Libya, New Zealand, USA, and USSR (Abou-Donia, 1996; El-Baradei et al., 2007b). The quality of Domiati cheese is high when it is manufactured from buffalo's milk due to the high solids content of buffalo's milk (15-17\% solids) compared to bovine's milk (12-14\% solids). Domiati cheese was manufactured from different varieties of milk, such as cow's milk (Fahmi et al., 1973; Fahmi and Sharara, 1950; Ibrahim et al., 1974; Ismail et al., 2010; Sharara, 1961a; Youssef et al., 1982a), buffalo's milk (Fahmi et al., 1973; A H Fahmi and Sharara, 1950; Ibrahim et al., 1974; Ismail et al., 2011; Rakshy and Attia, 1979; Sharara, 1961b; Youssef et al., 1982b), goat's milk (Mehaia, 2002; Rakshy and Hassan, 1971a), and camel's milk (Mehaia, 2006, 1993).

\section{Manufacturing of Domiati cheese}

Salt is added (8-15\%) to the milk, and then the rennet is added at $38^{\circ} \mathrm{C}$. Once the milk is coagulated (2-3 h), the curd is cut and ladled into molds and left between 12-24 h to drain the whey. The Domiati cheese is served fresh as it is after manufacturing or pickled in pickling solutions (Abd El-Salam et al., 1993; Abou-Donia, 1996). Pasteurization and adding starter cultures are recently utilized to keep the typical flavor of Domiati cheese and avoid adding an extensive quantity of salt as a preservative (Abd El-Salam et al., 1993; Abou-Donia, 1996). Adding single or a coculture of lactococci, lactobacilli, and enterococci was used in making Domiati cheese by many researchers (Abou-Donia, 1996). The Domiati $\mathrm{pH}$ is ranged from 6.0 to 6.5 (Abd El-Salam et al., 1993). Lactic acid bacteria (LAB) microflora (e.g., lactococci and lactobacilli) was found and isolated from the Domiati cheese surface. Lactococcus lactis subsp lactis, Lactobacillus casei, and Lactobacillus delbrueckii subsp bulgaricus were the main species of LAB isolated from Domiati cheese surface (Abou-Donia, 1996). Adding $7.5 \%$ of salt to the milk resulted in the presence of lactococci as the predominant of 
LAB in Domiati cheese, which is recently substituted by lactobacilli (LitopoulouTzanetaki, 2007). Increasing the addition of salt to $15 \%$ led to the presence of micrococci and lactobacilli as the majority of LAB. Enterococci were isolated from Domiati cheese, which exhibits high esterolytic activities (Hemati et al., 1997; LitopoulouTzanetaki, 2007).

Abou-Donia (1996) informed that the acidity of milk, starter cultures, milk treatments, additives, ripening, and storage temperatures affect the flavor of Domiati cheese. The soluble proteolysis products resulted from the Domiati cheese during ripening mixed with the brine to keep the stability with their content in the cheese (Abd El-Salam et al., 1993; Hayaloglu, 2017).

\section{The composition of Domiati cheese}

The moisture, fat, protein, and salt contents of Domiati cheese obtained from cow's milk, buffalo's milk, mixed of cow's and buffalo's milk, goat's milk, and camel's milk are shown in Figure 2. The moisture content of Domiati cheese made from cow's milk decreased from 59 to 55\% during 4-6 months of maturation or ripening period (A H Fahmi and Sharara, 1950). The moisture content of Domiati cheese that manufactured from different types of milk decreased due to the loss of the moisture content into the brine during the ripening period (El-Koussy et al., 1977; A H Fahmi and Sharara, 1950; Ismail et al., 2011; S. Rakshy and Attia, 1979; Rakshy and Hassan, 1971b). However, fat, protein, and salt contents of Domiati cheese increased with increasing the dry matter during the ripening period ( Fahmi and Sharara, 1950; Ismail et al., 2011; Rakshy and Attia, 1979; Rakshy and Hassan, 1971b). The $\mathrm{pH}$ of Domiati cheese decreased during the ripening or storage period. The $\mathrm{pH}$ of Domiati cheese made from cow's and buffalo's mixture using rennet as a coagulant decreased from 6.7 to
3.8 during the 4 months of ripening (Abdou et al., 1976). The $\mathrm{pH}$ of Domiati cheese that manufactured from cow's milk and whey proteins and ultrafiltered buffalo's milk decreased from 6.6 to 4.6 and 6.7 to 4.4 , respectively (Abd El-Salam et al., 1981; ElShibiny et al., 1973). The calcium and phosphorus contents of Domiati cheese obtained from cow's milk after manufacturing (fresh) were $0.96 \%$ and $0.70 \%$, respectively, and these values were approximately the same after $2 \mathrm{M}$ of ripening $0.96 \%$ and 0.69 , respectively (Omar and Buchheim, 1983). The calcium and phosphorus percentages were $0.59 \%$ and $0.14 \%$, respectively, after the manufacturing of Domiati cheese from cow's and buffalo's milk mixture (Sharara, 1956). The composition of Domiati cheese varies based on the types of milk, coagulation method, the age of cheese, additives, and conditions of cheese manufacture (AbouDonia, 1996).

\section{Karish cheese}

The Karish cheese is also soft, has known by the ancient Egyptians, and could be manufactured from skim cow's or buffalo's milk or a mixture of both (Abou-Donia, 1996). Karish cheese is traditionally manufactured from skim milk, so fat is separated by pouring the milk in pots known as Matrad or Shalia (Figure 2) and left in a warm place till the fat is separated and floated on the surface and the milk gets fermented or coagulated (Abou-Donia, 1996). The fat or cream is separated to produce butter oil while the fermented milk is consumed as it is (called Laban Rayeb) or to make Karish cheese which is consumed fresh or stored for more than one year to produce Mish cheese (Abou-Donia, 1984, 1996).

The earthenware pots made in the First Dynasty by the ancient Egyptians in 3200 BC and detected recently in the tomb of King Horaha. Also, mats or Shenda (Figure 3), 
which is commonly used to drain Karish cheese whey, and Zallaa or Ballas (Figure 4) which are used to store and pickle Mish cheese, were found in the temples of the Roman era (Engelbach, 1946). All of these clues prove that the Mish and Karish cheeses were known to the ancient Egyptians.

Karish cheese is an acid cheese which widely produced and consumed in the rural districts in Egypt (El-Gendy, 1983). Karish cheese is a white, soft cheese and has approximately $70 \%$ and $10 \%$ of moisture and fat contents, respectively. Karish cheese could be produced from Laban Rayeb, fresh skim milk, and buttermilk. It is served fresh or stored in a pickling solution in Ballas to produce Mish cheese (Abou-Donia, 1984, 1996; El-Gendy, 1983). Karish cheese has been investigated by many researchers and made from several varieties of milk, such as cow's milk (AbouDawood and Gomai, 1977; El-Sadek and Abd-El-Motteleb, 1958; El-Sadek and Motteleb, 1958; Ismail and El-Nahta, 1964; Ismail and El-Demerdash, 2003), buffalo's milk (Abd El-Tawab et al., 1988a; Awad et al., 2015; Hamad, 2001; Hussein and Shalaby, 2014; Ismail and El-Nahta, 1964; Ismail and El-Demerdash, 2003; Sameh, 2016; Wahba and El-Abbassy, 1982a, 1982b, 1982c), goat's milk (Ismail and ElDemerdash, 2003), and sheep's milk (Ismail and El-Demerdash, 2003).

\section{Manufacturing of Karish cheese}

\section{Traditional manufacturing process}

Karish cheese is made traditionally by leaving the raw milk in earthenware pots for 24-36 h during the summer season and 48-72 $\mathrm{h}$ during the winter season to produce the cream layer on the surface. The milk is coagulated by the natural microflora (Laban Rayeb). Then the cream layer is removed. The curd is poured into a mat for 2-3 days to drain the whey and obtain the desired texture of Karish cheese.
Then the salt is added, and cheese is cut into cubes and left for a couple of hours to drain the whey (Phelan et al., 1993). Karish cheese can be consumed as fresh cheese within 1-2 weeks shelf-life, or it can be pickled in Ballas (Figure 4) for more than a year (Abou-Donia, 1984, 1986; El-Gendy, 1983; Fox, 1993; Moustafa, 1967). The quantity of Karish cheese produced in Egypt is unknown; however, approximately $50 \%$ of the total produced milk in Egypt is employed for the manufacturing of Karish cheese (Moustafa, 1967).

\section{Large-scale manufacturing process}

Karish cheese is recently made in large scale factories. Cheesecloth was used for whey drainage instead of using the Shenda in the traditional method. The effects of different heat treatments were studied to maintain and standardize the flavor and the properties of Karish cheese. Pasteurized skim milk has been utilized in Karish cheese manufacture (Abdou and Dawood, 1977; Abou-Dawood and Gomai, 1977; Abou El Ella and Farahat, 1979; El-Sadek and Abd-El-Motteleb, 1958). In addition to pasteurization, adding starter cultures before manufacturing was studied to keep the typical flavor of Karish cheese. Many researchers have used single starters of lactococci, such as Lactococcus lactis subsp lactis and Lactococcus lactis subsp cremoris (El-Zayat and Omar, 1987) or yogurt starters which contained Lactobacillus delbrueckii subsp bulgaricus and Streptococcus salivarius subsp thermophilus (El-Alamy, 1984; ElShibiny et al., 1984) (Fig. 7). The best flavor was obtained in the Karish cheese, which was manufactured from Laban Rayeb, followed by the buttermilk and then skim milk (El-Gendy, 1983). This good flavor in Karish cheese made from Laban Rayeb is due to the favorable fermentation by natural microflora, which occurs in Laban Rayeb compared to the other two products. 


\section{The composition of Karish cheese}

The chemical composition of Karish cheese made from cow's milk, buffalo's milk, goat's milk, and sheep's milk is shown in Figure 6. The moisture content of fresh Karish cheese ranged from 69 to $77 \%$ (Ismail and ElDemerdash, 2003), and decreased during the ripening period. However, fat, protein, and salt contents increased with increasing the dry matter in the Karish cheese during storage (Abou-Dawood and Gomai, 1977; El-Sadek and Abd-El-Motteleb, 1958; El-Sadek and Motteleb, 1958; Ismail and El-Demerdash, 2003). The $\mathrm{pH}$ of Karish cheese decreased from 5.2 to 3.9 during the 3 months of ripening (Abou-Dawood and Gomai, 1977). The $\mathrm{pH}$ of Karish cheese varied depending on the coagulants used in the manufacturing and type of starter cultures. The calcium and phosphorus contents of Karish cheese immediately after manufacturing were $1.8 \%$ and $1.6 \%$, respectively (Abd El-Tawab et al., 1988b). The composition of Karish cheese varied within cheese samples, depending on the milk cheese type. Using skim milk in making Karish cheese resulted in manufacturing low-fat Karish cheese compared to utilizing whole milk (El-Sadek and Abd-El-Motteleb, 1958; El-Sadek and Motteleb, 1958; Ismail and El-Nahta, 1964).

\section{Mish cheese}

Mish cheese is a traditional dairy product (Figure 5) consumed by Egyptian farmers in rural areas and usually utilized as an appetizer (El-Gendy, 1983). Mish cheese is made by storing the Karish cheese in earthenware jars called Zallaa or Ballas (Figure 4) for more than one year for pickling and ripening. Mish cheese is a yellowish-brown cheese and has a sharp flavor with high salt content (El-Gendy, 1983). Mish cheese is mainly made from Karish cheese in the rural areas, while some wealthy farmers manufacture Mish cheese from whole milk with adding Ras cheese to it.
The ancient Egyptians have consumed a similar type of Mish cheese (Engelbach, 1961). The composition of Mish cheese (Figure 9) was investigated in many studies (Abou-Donia and El-Soda, 1986; A. F. ElErian et al., 1975; El-Gazzar and Monib, 1976; El-Zayat and El-Safty, 1985; Nassib and El-Gendy, 1974; Zaki and Shokry, 1988). It has been reported that Mish cheese had 4 groups of bacteria; Micrococci (60\%), bacilli (20\%), Arthrobacter (18\%) and anaerobic sporeformers (2\%) as shown in Figure 6 and the total aerobic bacterial count differed between samples (A. F. M. El-Erian et al., 1975).

\section{Manufacturing of Mish cheese}

The manufacturing process of Mish cheese has been described by many researchers (Abou-Donia, 1996; Abou-Donia and ElSoda, 1986; A. F. El-Erian et al., 1975; ElGendy, 1983; Hamdy and Taha, 1954). The process of making Mish cheese is different among areas in the same country; however, the principles steps are similar (Hamdy and Taha, 1954).

Mish cheese, which is obtained from Karish cheese, has a high content of moisture, so more water is removed from the Karish cheese before pickling. Therefore, Karish cheese is left after being manufactured in a dry place for several days (El-Gendy, 1983). The Karish cheese is then packed in layers in the Ballas (Figure 4), and salt is sprinkled on each layer. Then the container is filled with the pickling medium, which contains; buttermilk, Laban Rayeb, whey, and Mourta. Mourta is the residue ingredient after butter oil (Samna) manufacturing and consists of protein, fat, water, and salts. After adding the pickling medium into the Zalla or Ballas, some additives are added, such as spices (ground black pepper, cumin, and sharpflavored red pepper), annatto, 6-15\% salt, green pepper, and some old Mish as a natural 
starter (El-Gendy, 1983). El-Gendy (1983) reported that borax salts, such as sodium borate, could be added at the top of the Ballas as well as sharp red pepper and some spices tied in cheesecloth to kill Pyophilla casei larvae which contaminate the cheese during manufacturing. The Ballas is sealed with mud to provide anaerobic conditions and stored at room temperature for at least one year. OldMish cheese has a distinct sharp flavor similar to Roquefort or Romano cheese (Hamdy and Taha, 1954).

\section{The composition of Mish cheese}

The composition of Mish cheese is shown in Figure 9. The moisture, fat, protein, and salt contents of Mish cheese ranged from 43.00 to $76.00 \%, 0.07$ to $11.00 \%$. 9.50 to $14.00 \%$, and 9.40 to $12.90 \%$, respectively (Figure 9). The differences in Mish cheese composition could result from the differences in the composition of Karish cheese, composition of milk, composition of pickling solution, natural starter source, the amount of salt and different additives, ripening longevity, and the storage temperature. The calcium and phosphorus contents ranged from 0.36 to $0.39 \%$ and 0.32 to $0.39 \%$, respectively, in Mish cheese (Zaki and Shokry, 1988). The sodium chloride in Mich cheese is ranged from 9-13\%, as shown in Figure 9, whereas the potassium is $0.19 \%$ (Zaki and Shokry, 1988).

\section{Ras cheese}

Ras cheese is known in Egypt and Arab countries as Roumy cheese, and it is one of the leading traditional hard cheese in Egypt and Mediterranean countries (Hofi et al., 1970). It resembles the Greek Kefalotyri cheese, both originally being manufactured from goat's or cow's milk. It is manufactured under artisan conditions from cow's, buffalo's milk, or a mixture of both and consumed after
3 months of ripening when the pungent and sharp flavor is developed in the cheese (Hammam et al., 2018; Hofi et al., 1970; Phelan et al., 1993). Traditionally, Roumy cheese is manufactured from raw milk ( Ayad et al., 2004; Hammam et al., 2018; Hofi et al., 1970). Raw Roumy cheese showed high and acceptable flavors than pasteurized Roumy cheese due to the favorable fermentations that occur by the natural microflora in raw milk (Hammam et al., 2018; Hofi et al., 1970); however, flavors and composition had wide variations due to utilizing raw milk (AWAD, 2006).

According to the recent trend, all dairy products are supposed to be produced from pasteurized milk, so the Egyptian standards specify that Ras or Roumy cheese should be made from pasteurized milk and should contain not less than $60 \%$ solids and $45 \%$ fat in solids, and the final product must be free from pathogenic microorganisms. Roumy cheese has been examined by many researchers using different heat treatments and different starter cultures for manufacturing Roumy cheese with the typical flavor of Roumy cheese made from raw milk (Awad, 2006; Awad et al., 2007; Ayad et al., 2004; El-Neshawy, 1984; Hammam et al., 2018; Hofi et al., 1970; Kebary et al., 1999; Omar and Ashour, 1982).

\section{Manufacturing of Ras cheese}

\section{The traditional method of making Ras or Roumy cheese}

Raw milk is warmed at $32{ }^{\circ} \mathrm{C}$ in a cheese vat, and then rennet is added (6\%) into the milk. The milk is coagulated in approximately 45 min at $32{ }^{\circ} \mathrm{C}$. The curd is cut vertically and horizontally using 0.5 -inch knives. Then the temperature is increased from $32{ }^{\circ} \mathrm{C}$ to $45^{\circ} \mathrm{C}$ while the curd is stirred until the acidity reaches $0.14 \%$ (Hammam et al., 2018; Hofi et 
al., 1970). Two third of the whey is drained, and then $1.5 \%$ of salt is added and left for 15 min before drainage the rest of the whey. Then the cheese is pressed overnight, and salt is sprinkled again on the surface of cheese for one week before being coated with a plastic wax or sealed under vaccum (Hammam et al., 2018; Hofi et al., 1970).

Making Ras or Roumy cheese from pasteurized milk

Making Roumy cheese from pasteurized milk is similar to the traditional method. However, the milk is first pasteurized and cooled to 32 ${ }^{\circ} \mathrm{C}$ before adding the starter cultures. The starter culture is a mixture of Lactobacillus delbrueckii subsp. bulgaricus and Streptococcus thermophilus with a ratio of $1: 1$. The rennet is added as described by Hofi et al., (1970) and Hammam et al., ( 2018) when the acidity increases to $0.19 \%$. The milk is coagulated in $45 \mathrm{~min}$ and then cut, heated, salted, and pressed as described in the traditional method.

Figure.1 Flowchart of the cheese production process in the plant

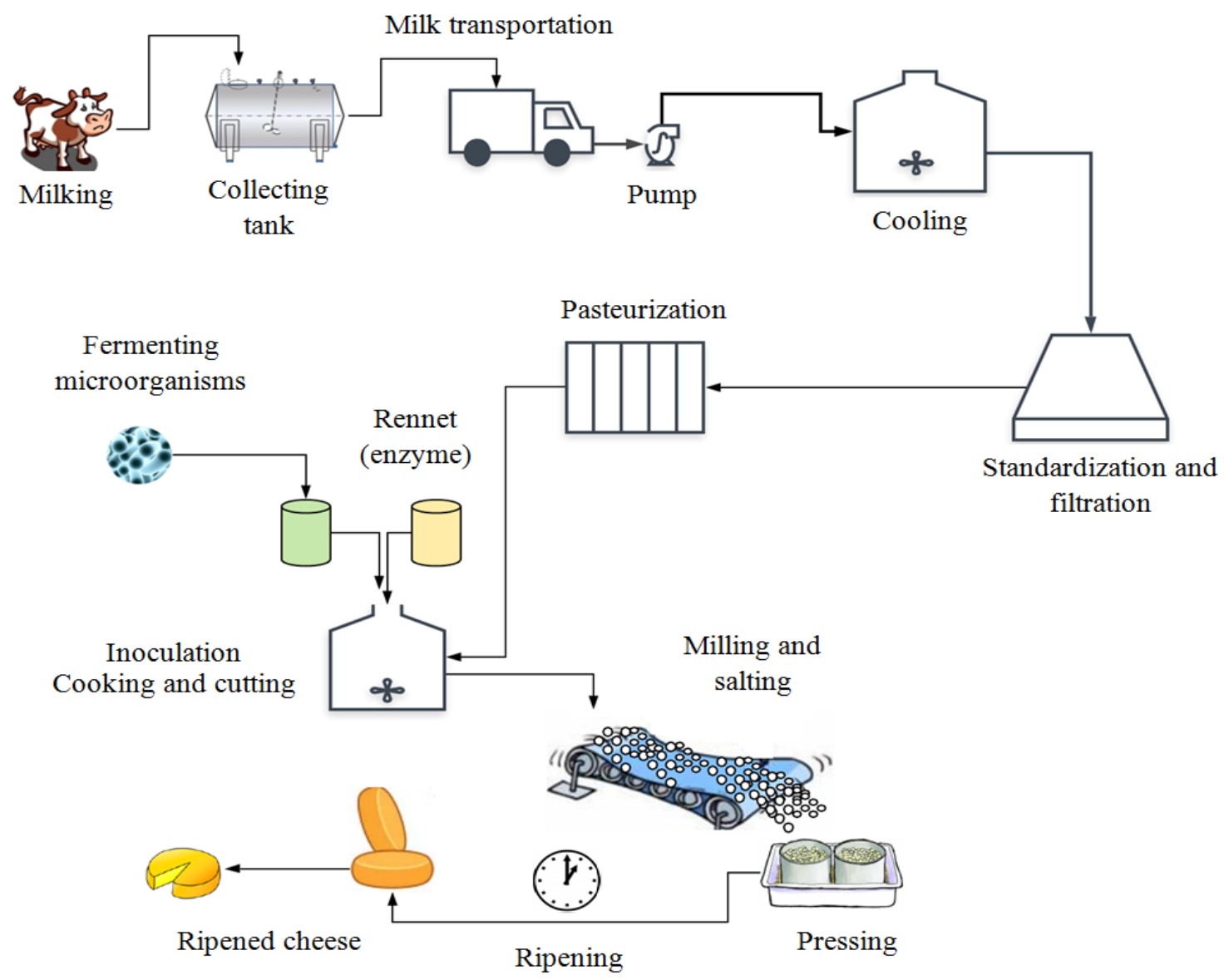


Figure.2 The Domiati cheese composition obtained from several verities of milk during ripening

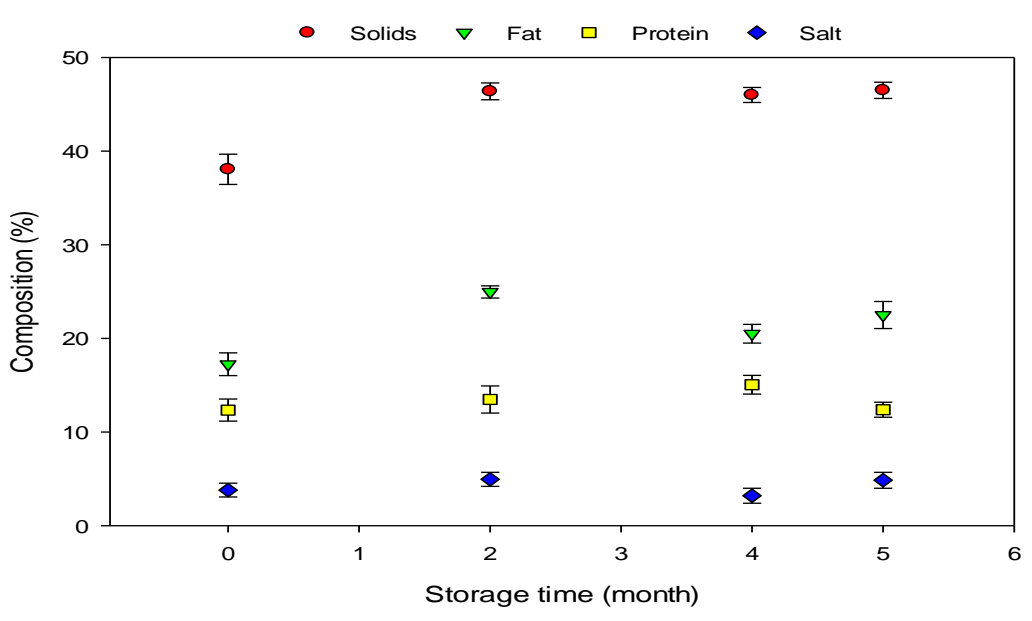

Figure.3 Matrad or Shalia used for raw milk fermentation to manufacture Karish cheese or Laban
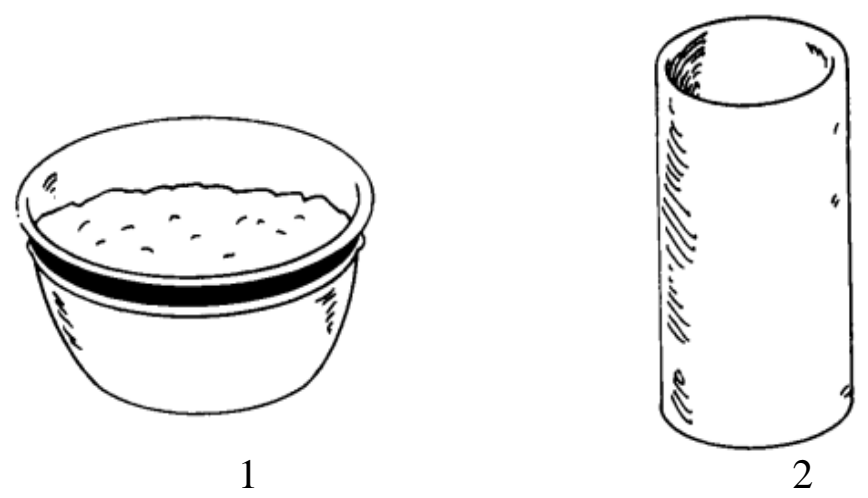

Figure.4 Mat or Shenda (a type of reed) used to drain Karish cheese curd from the whey

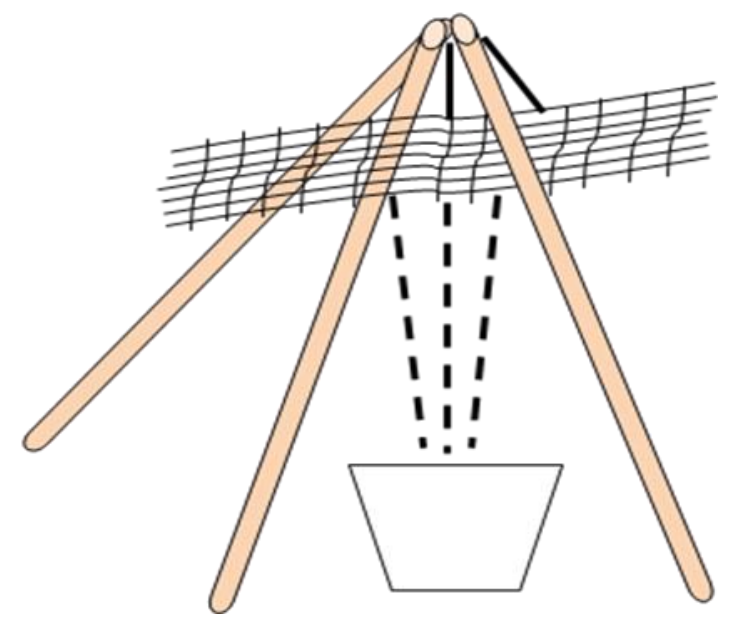


Figure.5 Different shapes of Ballas or Zalla used for ripening and storage Mish cheese. Adopted from (a) Ahmed (2018); (b) Atom (2014); and (c) El-Gendy (1983)

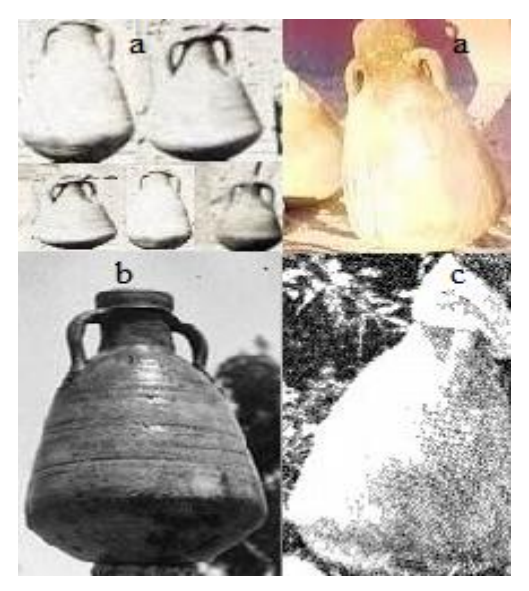

Figure.6 The Karish cheese composition made from several varieties of milk

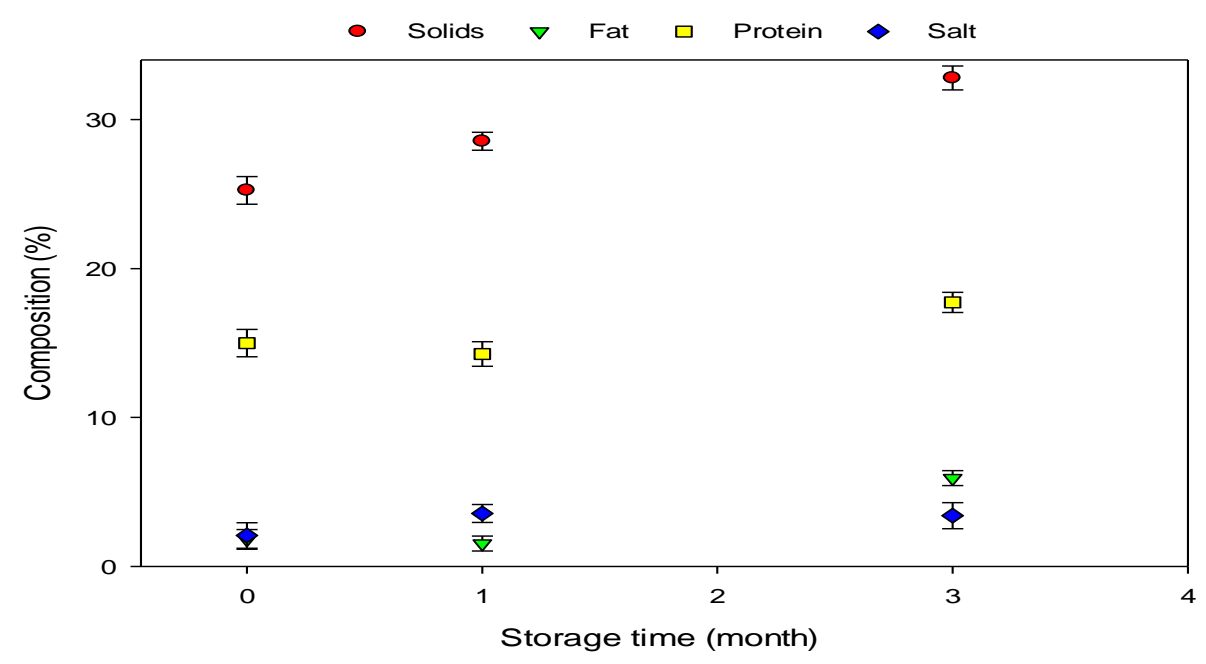

Figure.7 Ripened Mish cheese. Adopted from Mlakaty (2013)

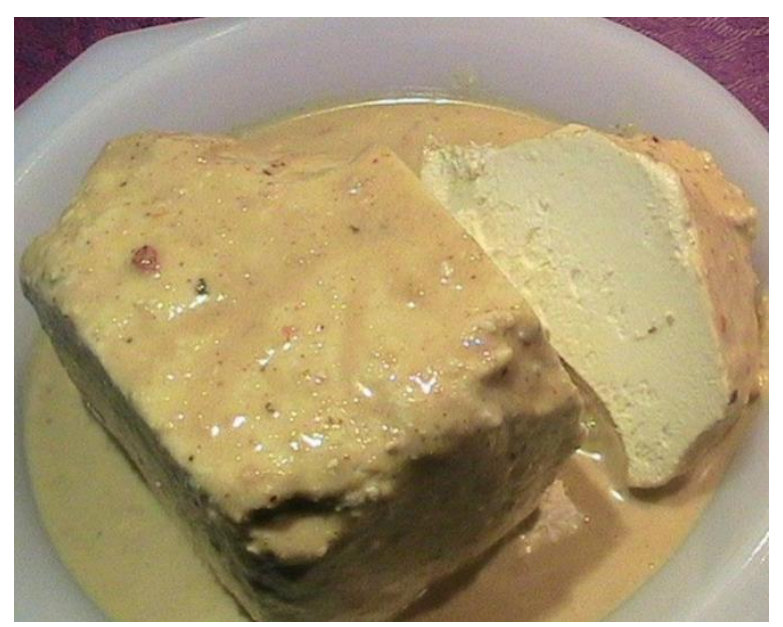


Figure.8 The percentage of microbial flora content in Mish cheese. Adopted from (El-Erian and El-Gendy, 1975)

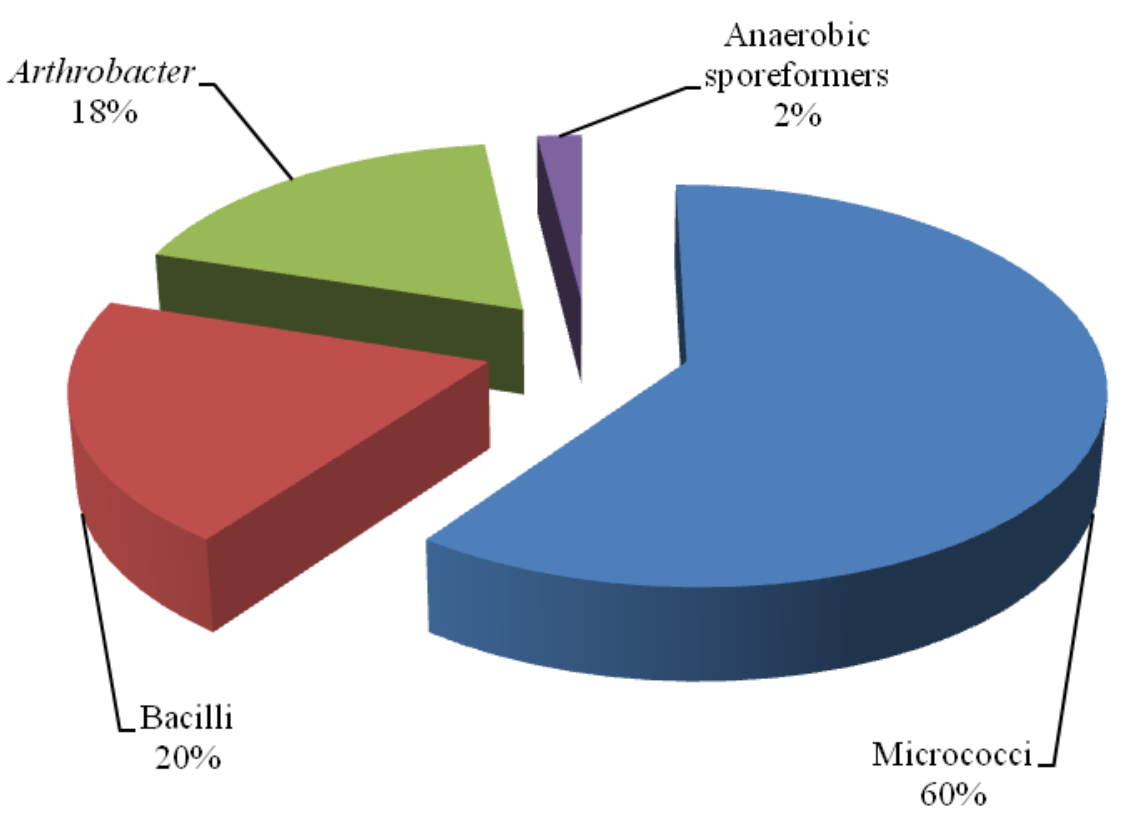

Figure.9 The chemical composition of Mish cheese

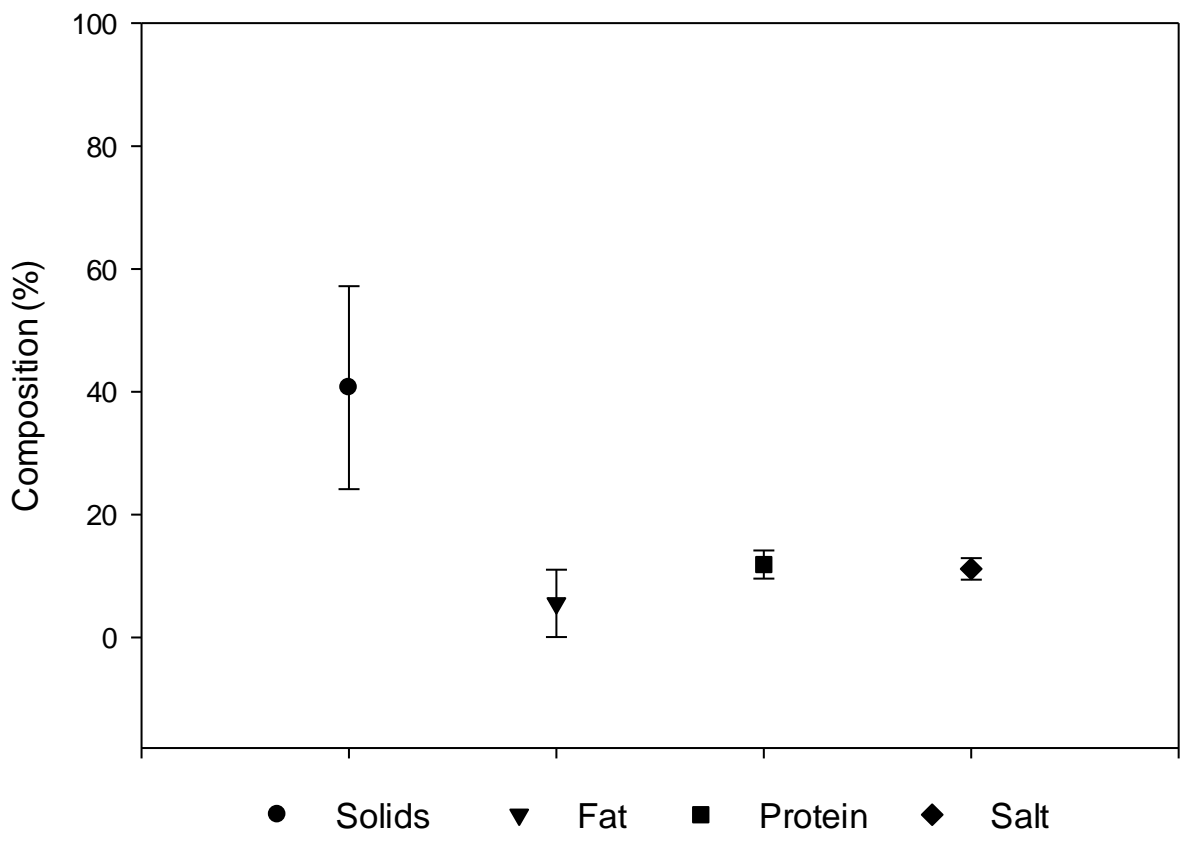


Figure.10 The composition of Ras cheese during ripening

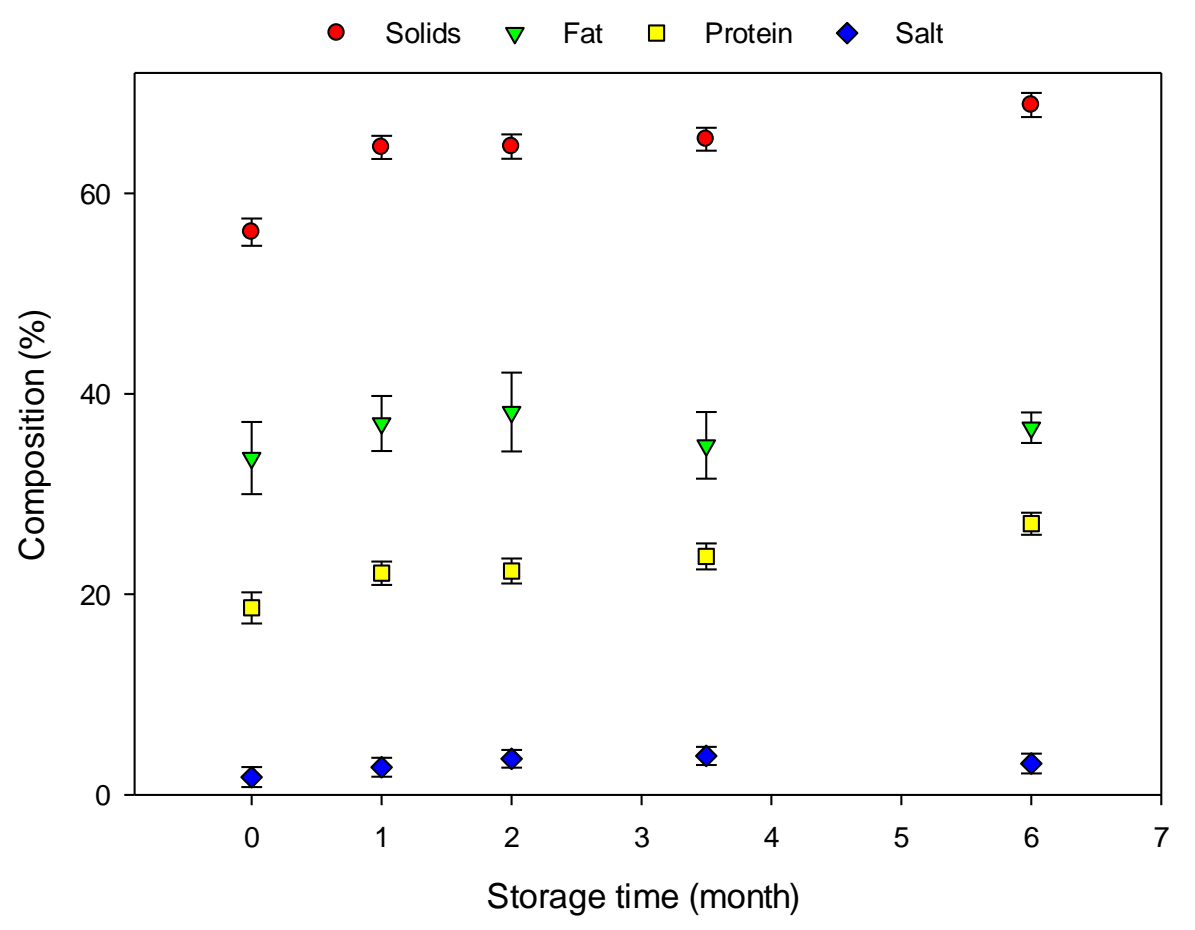

\section{The composition of Ras cheese}

Figure 10 is shown the composition of Roumy cheese. The moisture content in fresh Roumy cheese is approximately 40\% (AWAD, 2006; El-Neshawy, 1984; Hofi et al., 1970) and can reach up to 47-49\% (Awad et al., 2007; Hammam et al., 2018; Kebary et al., 1999; Omar and Ashour, 1982) depending on the milk types and the processing method. The moisture content of Roumy cheese decreases during the ripening period (AWAD, 2006; Awad et al., 2007; El-Neshawy, 1984; Hammam et al., 2018; Hofi et al., 1970; Kebary et al., 1999; Omar and Ashour, 1982) and thereby increasing the fat, protein, and salt contents as a result of increasing the solids. The Roumy cheese that obtained from a mix of cow's milk and buffalo's milk (1:1) after 6 months of ripening had approximately $30 \%, 39 \%, 27$ and $2 \%$ of moisture, fat, protein and salt, respectively (Hofi et al., 1970), while Roumy cheese made from a mixture of cow's milk and buffalo's milk (4:1) after 6 months of ripening had around
$32 \%, 34 \%, 27$ and $4 \%$ of moisture, fat, protein and salt, respectively (AWAD, 2006). The composition of Roumy cheese varies based on the type of milk used in cheese manufacture, additives, and starter cultures.

\section{The health benefits of cheese}

Cheese is an essential food for maintaining healthy bone growth in children and young people. It is a rich dietary source of calcium, protein, magnesium, zinc, and vitamins $\mathrm{A}$ and D, so it positively influences bone health from osteoporosis (Bonjour et al., 2012). Also, calcium plays a vital role in the formation of teeth, and cheese is a good source of calcium. Also, a study showed that consumption of cheese provides protection against tooth decay (Adegboye et al., 2012). Additionally, some cheeses, especially white cheeses made from cow's milk, are found to be rich in omega-3 fatty acids that benefit the cardiovascular system and brain (Sofi et al., 2010). 
In conclusion, cheese is a dairy product that considers essential daily food for many people around the world. Cheese has shelf-life longer than milk. It has a nutritional value that provides an essential source of digestible protein and minerals, including calcium and phosphorus. Cheese is a dairy food essential for building healthy bones and teeth. There are several soft and hard cheese varieties in Egypt made from cow's, buffalo's, camel's, goat's, and sheep's milk. This review discussed the technological and chemical properties of the most popular soft and hard cheeses and their health benefits in Egypt and other countries.

\section{References}

Abd El-Salam, M.H., Alichanidis, E., Zerfiridis, G.K., 1993. Domiati and Feta type cheeses, in: Fox, P.F. (Ed.), Cheese: Chemistry, Physics and Microbiology. Springer, Boston, MA, pp. 301-335. https://doi.org/https://doi.org/10.1007/9 78-1-4615-2648-3_11

Abd El-Salam, M.H., El-Shibiny, S., Ahmed, N.S., Ismail, A.A., 1981. The use of ultrafiltration in manufacture of Domiati cheese from buffalo's milk. Egypt. J. Dairy Sci. 9, 151-157.

Abd El-Tawab, G., El-Din, A.G., ElDemerdash, O., Zedan, M., 1988a. Chemical composition and nutritive value of Kareish cheese from buffalo skim milk. Egypt. J. Dairy Sci. 16, 6570.

Abdou, S.M., Dawood, A.H.M., 1977. Effect of heat treatment of skim milk on yield, quality and chemical composition of skim milk cheese (Kariesh). Egypt. J. Dairy Sci. 5, 1-5.

Abdou, S.M., Ghita, I., El-Shibiny, S., 1976. Use of microbial rennets and pepsin in the manufature of Domiati cheese. Egypt. J. dairy Sci. 4, 147.
Abou-Dawood, A.E., Gomai, A.Y., 1977. use of high total solids reconstituted skim milk in Kareish cheese making. Egypt. J. Dairy Sci. 5, 229-234.

Abou-Donia, S., 1984. Egyptian fresh fermented milk products. New Zeal. J. Sci. Technol. 19, 7-18.

Abou-Donia, S.A., 1996. Manufacture of Egyptian, soft and pickled cheeses, in: Robinson, R.K., Tamime, A.Y. (Eds.), Feta and Related Cheeses. Woodhead Publishing, pp. 160-208. https://doi.org/https://doi.org/10.1533/9 781845698225.160

Abou-Donia, S.A., 1986. Egyptian Domiati soft white pickled cheese. New Zeal. J. Dairy Sci. Technol. 21, 167-190.

Abou-Donia, S.A., El-Soda, M.A., 1986. Egyptian soft pickled ripened mish cheese. Indian J. Dairy Sci. 29, 1-5.

Abou El Ella, W.M., Farahat, S.M., 1979. Studies on soft cheese with low fat and salt contents. Milchwissenschaft 34, 8990.

Adegboye, A.R.A., Twetman, S., Christensen, L.B., Heitmann, B.L., 2012. Intake of dairy calcium and tooth loss among adult Danish men and women. Nutrition 28 , 779-784. https://doi.org/https://doi.org/10.1016/j. nut.2011.11.011

Ahmed, S., 2018. The beautiful time (Photos and ancient places) [WWW Document]. Google Plus. URL https://plus.google.com/photos/photo/11 $2717908743399832052 / 661219630024$ 0019474 (accessed 10.14.18).

Atom, 2014. The Ballas of Mish [WWW Document]. Mitsalsil2. URL http://mitsalsil2.blogspot.com/2014/12/ blog-post_74.html (accessed 12.20.14).

Awad, R.A., Salama, W.M., Ragb, W.A., 2015. Enhancing yield and acceptability of Kareish cheese made of Reformulated milk. Ann. Agric. Sci. 60, 87-93. 
https://doi.org/10.1016/j.aoas.2015.03.0 04

AWAD, S., 2006. Texture and flavour development in Ras cheese made from raw and pasteurised milk. Food Chem. 97,

394-400.

https://doi.org/10.1016/j.foodchem.2005 .05 .012

Awad, S., Ahmed, N., Soda, M. El, 2007. Evaluation of isolated starter lactic acid bacteria in Ras cheese ripening and flavour development. Food Chem. 104, 1192-1199.

https://doi.org/10.1016/j.foodchem.2007 .01 .043

Ayad, E.H.E., 2009. Starter culture development for improving safety and quality of Domiati cheese. Food Microbiol. 26, 533-541. https://doi.org/https://doi.org/10.1016/j.f m.2009.03.007

Ayad, E.H.E., Awad, S., El-Attar, A., De Jong, C., El-Soda, M., 2004. Characterisation of Egyptian Ras cheese. 2. Flavour formation. Food Chem. 86, 553-561. https://doi.org/10.1016/j.foodchem.2003 .10 .002

Ayad, E.H.E., Awad, S., El Attar, A., de Jong, C., El-Soda, M., 2004. Characterisation of Egyptian Ras cheese. 2. Flavour formation. Food Chem. 86, 553-561. https://doi.org/10.1016/j.foodchem.2003 .10 .002

Bonjour, J.-P., Benoit, V., Rousseau, B., Souberbielle, J.-C., 2012. Consumption of Vitamin D-and Calcium-Fortified Soft White Cheese Lowers the Biochemical Marker of Bone Resorption TRAP 5b in Postmenopausal Women at Moderate Risk of Osteoporosis Fracture. J. Nutr. 142, 698-703. https://doi.org/10.3945/jn.111.153692

El-Alamy, H.A.A.E.-S.M. E.-S.S., 1984. Production of skim milk (Karish cheese) from ultrafiltered reconstituted milk. Egypt. J. Dairy Sci. 12, 111-115.

El-Baradei, G., Delacroix-Buchet, A., Ogier, J.-C., 2007a. Biodiversity of Bacterial Ecosystems in Traditional Egyptian Domiati Cheese. Appl. Environ. Microbiol. 73, 1248 LP-1255. https://doi.org/https://doi.org/10.1128/A EM.01667-06

El-Baradei, G., Delacroix-Buchet, A., Ogier, J.-C., 2007b. Biodiversity of Bacterial Ecosystems in Traditional Egyptian Domiati Cheese. Appl. Environ. Microbiol. 73, 1248-1255. https://doi.org/10.1128/AEM.01667-06

El-Erian, A.F., Farag, A.H., El-Gendy, S.M., 1975. Chemical studies on mish cheese. Agric. Res. Rev. 53, 173.

El-Erian, A.F.M., El-Gendy, S.M., 1975. Bacteriological studies on Mish cheese. Egypt. J. Dairy Sci. 3, 29-37.

El-Erian, A.F.M., Farag, A.H., El-Gendy, S.M., 1975. Chemical studies on mish cheese. Agric. Res. Rev 53, 173.

El-Gazzar, H., Monib, A., 1976. Relation between density (degree Baume and specific gravity) and total solids or titratable acidity of condensed whey. Agric. Res. Rev. 54, 155-160.

El-Gendy, S.M., 1983. Fermented foods of Egypt and the Middle East. J. Food Prot. 46, 358-367. https://doi.org/https://doi.org/10.4315/0 362-028X-46.4.358

El-Koussy, L., Cheded, M.A., Foda, E.A., Hamdy, A.M., 1977. Preparation of milk clotting enzymes from plant sources. III.-Domiati cheese making using the extracted enzyme from Solanum torvum [Egypt]. Egypt. J. Dairy Sci.

El-Neshawy, A., 1984. Improving the quality of Ras cheese made without starter. Food Chem. 14, 201-213. https://doi.org/10.1016/03088146(84)90059-1 
El-Sadek, G.M., Abd-El-Motteleb, L., 1958. 698. Effect of the heat treatment of milk on the yield, quality and certain properties of standardized separated milk cheese. J. Dairy Res. 25, 85-91. https://doi.org/https://doi.org/10.1017/S 0022029900009067

El-Sadek, G.M., Motteleb, L.A. El, 1958. 739. The effect of heat treatment and temperature of storage on the yield, quality and chemical composition of karish cheese. J. Dairy Res. 25, 480 485.

https://doi.org/10.1017/S002202990000 9547

El-Shibiny, S., Abd El-Salam, M.H., Ahmed, N.S., 1973. Effect of some additives on the yield, quality and chemical composition of Domiati cheese. II. Whey proteins. Egypt. J. Dairy Sci 1, $56-62$.

El-Shibiny, S., El-Salam, M.H., Mahfouz, M.B., El-Alamy, H.A., 1984. Effect of coagulation method on composition and quality of skimmilk (Karish) cheese made by ultrafiltration technique. Egypt. J. Dairy Sci 12, 243-250.

El-Zayat, A.I., El-Safty, M.S., 1985. Chemical composition and bacteriological quality of Mish [Egypt]. Egypt. J. Food Sci. 13, 57-62.

El-Zayat, A.I., Omar, M.M., 1987. Kareish cheese prepared from ultrafiltered milk. J. Dairy Res. 54, 545-550. https://doi.org/10.1017/S002202990002 5747

Engelbach, R., 1961. Introduction to Egyptian Archaeology, with Special Reference to the Egyptian Museum, Second Edit. ed. General Organisation for Government Printing Offices, Cairo.

Engelbach, R., 1946. Introduction to Egyptian Archaeology, with Special Reference to the Egyptian Museum, Cairo. Imprimerie de l'Institut français d'archéologie orientale.
Fahmi, A.H., Metwaly, M., Abou-Dawood, A.E., Abd El-Salam, I., 1973. The effect of the amount rennet and renneting temperature on Domiati cheese. Egypt. J. Dairy Sci 1, 63-70.

Fahmi, A.H., Sharara, H.A., 1950. 429. Studies on Egyptian Domiati cheese. J. Dairy Res. 17, 312-328 https://doi.org/https://doi.org/10.1017/S 0022029900005860

Fox, P.F., 1993. Cheese: an overview, in: Fox, P.F. (Ed.), Cheese: Chemistry, Physics and Microbiology. Springer, pp. 1-36.

Fox, P.F., McSweeney, P.L.H., 2004. Cheese: An Overview, in: Cheese: Chemistry, Physics and Microbiology. Springer, pp. 1-18. https://doi.org/10.1016/S1874558X(04)80060-5

Hamad, B., 2001. Effect of Starter Culture on The Quality and Yield of Karish Cheese Made From Buffalo' s M ilk By. Mansoura Univ. J. Food Dairy Sci. 1-9.

Hamdy, M.K., Taha, S.M., 1954. A SoftRipened Egyptian Cheese. Milk Prod. J. 45, 22.

Hammam, A.R.A., Tammam, A.A., ElRahim, A.M.A., 2018. Effect of different heat treatments on the characteristics of Ras cheese during ripening. Egypt. J. Dairy Sci. 46, 111119.

Hayaloglu, A.A., 2017. Cheese Varieties Ripened Under Brine, in: Fox, P.F., McSweeney, P.L.H., Cogan, T.M., Guinee, T.P. (Eds.), Cheese: Chemistry, Physics and Microbiology: Fourth Edition. Academic Press, pp. 997-1040. https://doi.org/10.1016/B978-0-12417012-4.00039-9

Hellmuth, K., van den Brink, J.M., 2013. Microbial production of enzymes used in food applications, in: McNeil, B., Archer, D., Giavasis, I., Harvey Enzymes and Nutraceuticals, L.B.T.M.P. of F.I. (Eds.), Microbial 
Production of Food Ingredients, Enzymes and Nutraceuticals. Elsevier, pp. 262-287. https://doi.org/10.1533/9780857093547. 2.262

Hemati, B., Suessmuth, R., Beutling, D., ElSoda, M., 1997. Characterization of strains of the genus Enterococcus isolated from Egyptian Domiati cheese. Arch. fuer Leb. 48, 17-20.

Hofi, A.A., Youssef, E.H., Ghoneim, M.A., Tawab, G.A., 1970. Ripening changes in Cephalotyre "RAS" cheese manufactured from raw and pasteurized milk with special reference to flavor. J. Dairy Sci. 53, 1207-1211. https://doi.org/10.3168/jds.S00220302(70)86369-X

Hussein, G.A.M., Shalaby, S.M., 2014. Microstructure and textural properties of Kareish cheese manufactured by various ways. Ann. Agric. Sci. 59, 25 31.

https://doi.org/https://doi.org/10.1016/j. aoas.2014.06.004

Ibrahim M.K.E., Fahmi A.H., Amer S.N., M.A.E.M., 1974a. Effect of kind of milk on the percentage distribution of milk constituents and added salt between Domiati cheese and whey. Dairy Sci. 2 1, 143-148.

Ismail, A.A., El-Nahta, A., 1964. The variation between buffaloe's and cow's milk in" Kariesh" cheese-making. Alexandria J. Agric. Res. 12, 195-203.

Ismail, M.M., Ammar, E.M.A., El-Shazly, A.A., Eid, M.Z., 2010. Impact of cold storage and blending different lactations of cows milk on the quality of Domiati cheese. African J. Food Sci. 4, 503-513.

Ismail, M.M., Ammar, E.M.A., Khalil, A.E., Eid, M.Z., 2011. Properties of domiati cheese as affected by blending various milkings and cold storage of buffalo's milk. J. Food Dairy Sci. Mansoura Univ. 2, 641-655.
Ismail, M.M., El-Demerdash, M.E., 2003. Effect of milk type and coagulant on physical properties, yield. Chemical composition and organoleptic properties of Kareish cheese. Egypt. J. Appl. Sci. $18,240-253$.

Kebary, K.M.., El-Sonbaty, A.., Badawi, R.., 1999. Effects of heating milk and accelerating ripening of low fat Ras cheese on biogenic amines and free amino acids development. Food Chem. 64, 67-75.

https://doi.org/10.1016/S0308-8146 (98)00085-5

Litopoulou-Tzanetaki, E., 2007. Soft-ripened and fresh cheeses: Feta, quark, halloumi and related varieties, in: Weimer, B.C. (Ed.), Improving the Flavour of Cheese. Elsevier, pp. 474-493. https://doi.org/10.1533/9781845693053. 4.474

Mehaia, M.A., 2006. Manufacture of fresh soft white cheese (Domiati type) from dromedary camel's milk using ultrafiltration process. J. food Technol. 4, 206-212.

Mehaia, M.A., 2002. Manufacture of fresh soft white cheese (Domiati-type) from ultrafiltered goats' milk. Food Chem. 79 , 445-452.

https://doi.org/10.1016/S03088146(02)00195-4

Mehaia, M.A., 1993. Fresh Soft White Cheese (Domiati-Type) from Camel Milk: Composition, Yield, and Sensory Evaluation. J. Dairy Sci. 76, 28452855.

https://doi.org/10.3168/jds.S00220302(93)77623-7

Mlakaty, M., 2013. How to make Mish cheese at home [WWW Document]. ShahyaTayba. URL http://shahyatayba.blogspot.com/2013/02/blogpost_3671.html (accessed 2.28.13).

Moustafa, Y.A., 1967. Studies on some bacteriological and chemical properties 
of Kariesh cheese. M.Sc Thesis. Faculty of Agriculture, Ain Shams University, Cairo, Egypt.

Nassib, T.A., El-Gendy, S.M., 1974. Chemical and microbiological studies on Mish. Ann Agric Sci Moshtohor 1, 149-154.

Omar, M.M., Ashour, M.M., 1982. Studies in the use of recombined milk for the manufacture of ras cheese. Food Chem. 8, 33-41. https://doi.org/10.1016/03088146(82)90055-3

Omar, M.M., Buchheim, W., 1983. Composition and Microstructure of Soft Brine Cheese Made From Instant Whole Milk Powder. J. Food Struct. 2, 43-50.

Phelan, J.A., Renaud, J., Fox, P.F., 1993. Some non-European cheese varieties, in: Fox, P.F. (Ed.), Cheese: Chemistry, Physics and Microbiology. Springer, Boston, MA, pp. 421-465. https://doi.org/https://doi.org/10.1007/9 78-1-4615-2648-3_14

Rakshy, S., Attia, I., 1979. The suitability of cow's and buffaloes' milk for the manufacturing of a pickled cheese variety without salting the milk. 1 . Manufacturing of the cheese [in Egypt]. Alexandria J. Agric. Res. 27, 355-358.

Rakshy, S.E., Attia, I., 1979. The suitability of cow's and buffaloes' milk for the manufacturing of a pickled cheese variety without salting the milk. 1 . Manufacturing of the cheese [in Egypt]. Alexandria J. Agric. Res.

Rakshy, S.E., Hassan, N., 1971a. Suitability of Goats Milk for the Manufacture of a Pickled Cheese Variety. Alexandria J Agr Res.

Rakshy, S.E., Hassan, N., 1971b. The suitability of goat milk for the manufacture of a pickled cheese variety. Alexandria J Agr Res 19, 269-272.

Sameh, A., 2016. Microbial safety criteria and quality of traditional Egyptian Karish cheese. African J. Microbiol. Res. 10,
804-812.

https://doi.org/10.5897/AJMR2016.802 2

Sharara, H.A., 1961a. Composition of Domiati cheese made from cow and buffalo's milk. Agric. Res. Rev. Cairo 39, 168-200.

Sharara, H.A., 1961b. Composition of Domiati cheese made from cow and buffalo's milk. Agric. Res. Rev. 39, 168-200.

Sharara, H.A., 1956. Retention of calcium and phosphorus in Egyptian Domiati cheese. Indian J. Dairy Sci. 9, 17-23.

Sofi, F., Buccioni, A., Cesari, F., Gori, A.M., Minieri, S., Mannini, L., Casini, A., Gensini, G.F., Abbate, R., Antongiovanni, M., 2010. Effects of a dairy product (pecorino cheese) naturally rich in cis-9, trans-11 conjugated linoleic acid on lipid, inflammatory and haemorheological variables: A dietary intervention study. Nutr. Metab. Cardiovasc. Dis. 20, 117124.

https://doi.org/10.1016/j.numecd.2009.0 3.004

Wahba, A., El-Abbassy, F., 1982a. Manufacture of Kareish cheese without starter. I. The use of lactic, acetic and hydrochloric acids. Egypt. J. dairy Sci.

Wahba, A., El-Abbassy, F., 1982b. Manufacture of Kareish cheese without starter. II. Effect of storage (pickling). Egypt. J. dairy Sci.

Wahba, A., El-Abbassy, F., 1982c. Manufacture Kareish cheese without starter. III. Effect of pepsins and fungal rennets. Egypt. J. dairy Sci.

Wolfschoon, A., 2010. Cheese Technology. Int. Dairy J. 20, 222 https://doi.org/10.1016/j.idairyj.2009.12 .001

Youssef, A.M., Salama, F.A., Ismail, A.A., Salem, S.A., 1982a. Comparative studies on white pickled Brinza cheese 
made from cows' and buffaloes' milk in Egypt. IV. Effect of pickling conditions on yield and organoleptic properties. Egypt. J. dairy Sci.

Youssef, A.M., Salama, F.A., Ismail, A.A., Salem, S.A., 1982b. Comparative studies on white pickled Brinza cheese made from cows' and buffaloes' milk in
Egypt. IV. Effect of pickling conditions on yield and organoleptic properties. Egypt. J. Dairy Sci. 10, 261-266.

Zaki, N., Shokry, Y.M., 1988. Chemical and microbiological changes in mish cheese and mish during ripening. Egypt. J. Dairy Sci. 16, 119-129.

\section{How to cite this article:}

Ahmed R. A. Hammam, Mohamed S. Elfaruk, Mahmoud E. Ahmed and Venkateswarlu Sunkesula. 2020. Characteristics and Technological Aspects of the Egyptian Cheeses. Int.J.Curr.Microbiol.App.Sci. 9(06): 3338-3354. doi: https://doi.org/10.20546/ijcmas.2020.906.397 